\title{
Characterization of Wheat and Barley Entries for Foliar Blight Resistance
}

\author{
Elangbam Premabati Devi* and S.I. Patel \\ Wheat Research Station, Sardarkrushinagar Dantiwada Agricultural University, \\ Vijapur 382 870, Mehsana, Gujarat, India \\ *Corresponding author
}

\begin{tabular}{l} 
K e y w o r d s \\
$\begin{array}{l}\text { Alternaria triticina, } \\
\text { Bipolaris sorokiniana, } \\
\text { Leaf tip necrosis, Host } \\
\text { resistance }\end{array}$ \\
\hline Article Info \\
$\begin{array}{l}\text { Accepted: } \\
\text { 22 July } 2018 \\
\text { Available Online: } \\
\text { 10 August } 2018\end{array}$ \\
\hline
\end{tabular}

A B S T R A C T
The most economic way to manage the foliar blight of wheat is through resistance breeding. The present investigation was carried out to gather information about the hundred entries possessing resistant to spot blotch at field under epiphytotic condition of 2016-17 crop season. Among twenty five entries of wheat, ten entries i.e. GW 322, GW 492, GDW 1255, Raj 4315, Raj 3765, VA 2015-30, VA 2015-41, JD 2015-18, VD 15-26, and VD 2016-1 were found with no infection of foliar blight in all three stages hence their values of AUDPC were zero. While, the highest score of foliar blight were recorded in two varieties; Bansi and A-9-30-1 with 89 and 79 respectively, in hard dough stage. Among barley entries, three entries viz., PL 751, VW 2016-7 and RD 2715 were associated with highest severity score ranging from 69 to 79 so categorized as moderately susceptible to susceptible reaction and their values of AUDPC were ranged from 1605 to 1672.5. Values of AUDPC for all entries were ranged from 0 to 1657.5 as compared to susceptible varieties, Bansi and A-9-30-1 which recorded with AUDPC values of 2122.5 and 1672.5 respectively. It was observed that out of seventy five entries of wheat, fifty eight and nine entries were highly resistant and resistant while among twenty five entries of barley, three and four entries were highly resistant and resistant respectively to foliar blight. Thus, these diverse sources of resistance entries can be used for enhancing crossing programme for developing foliar blight resistant variety of wheat and barley.

\section{Introduction}

Foliar blight of wheat has been reported to be associated with Alternaria triticina Prasada and Prabhu and Bipolaris sorokiniana (Sacc.) Shoemaker because of their saprophytic nature of pathogen (Maraite et al., 1998; Chaurasia et al., 2000; Mishra et al., 2011) and report has suggested that it also infect on barley (Khudhair et al., 2014). The presence of high relative humidity which allows the canopy to remain wet for a prolonged period make favourable for infection and pathogen growth (Acharya et al., 2011) and disease spreads when the temperature remain at $>26^{\circ} \mathrm{C}$ (Chaurasia et al., 2000), so making more vulnerable in late sown wheat (Duveiller et al., 2005). Alternaria leaf blight is considered as most important disease in most of the wheat growing states of India (Prabhu and Prasada, 1970; Mishra et al., 1989; Sharma et al., 1998). Moreover, the pathogen has been reported from North Africa (Anahosur, 1978), Mexico (Waller, 1981), Bangladesh (Ahmed 
and Ahmed 1994), France (Logrieco et al., 1990), Greece (Logrieco et al., 1990), Egypt (Beshir, 1994), China (Guo, 2005), Argentina (Perello and Sisterna, 2006) and Iraq (Khudhair et al., 2014). Infected seeds developed often shrivelled with a brown discoloration of the seed surface (Prabhu and Prasada, 1966). Infected seeds developed as small seeds with 46-75 per cent reduction in grain weight (Raut et al., 1983). While, association of Bipolaris sorokiniana (Sacc.) Shoemaker in foliar blight of wheat and barley has been reported due to its wide spread prevalence and severe intensities with its increasing concern in India and South East Asia where warm and humid environments of 18 to $32^{\circ} \mathrm{C}$ occur (Joshi et al., 2002, 2007; Chand et al., 2003; Kumar et al., 2014). The pathogen occurs mainly in North-Eastern Plains Zone of India encompassing Eastern U.P., Bihar, West Bengal, Orissa, Assam and other North Eastern States (Chaurasia et al., 2000). The disease was appeared in severe form in Uttar Pradesh on varieties HD 2329 and HD 2285 during 1990-91 which was mainly due to late sowing and warm humid environment in March (Singh et al., 1993). In Gangetic plains of India, it is the major biotic constraint in wheat production where ricewheat cropping systems were adopted (Duveiller et al., 1998). Besides, the extensive use of conservation tillage practices may possibly be favourable for the higher intensity of spot blotch incidence in the South East Asia (Duveiller and Sharma, 2009). The yield losses of 27 to 56.6 per cent during 1998-99 were reported in North Eastern and North Western Plains of India due to the leaf blight (Satvinder et al., 2002) and 6.3 to 50.6 per cent of yield losses have been reported due to foliar blight influenced by cultivars and agro climatic zones (Singh et al., 2004). The most economical and effective strategy to manage the disease is planting of resistant cultivars (Duveiller 2004; Duveiller and Sharma 2009; Sharma et al., 2007).
But the main cause for slow progress in resistance breeding for foliar blight has been suggested to polygenic nature of resistance (Dubin and Van Ginkel, 1991; Duveiller et al., 1998; Joshi et al., 2004b). While, several morphological characteristics of the host plant like waxy coating on leaf surface and leaf angle may be positively correlated with the resistance to spot blotch (Joshi and Chand, 2002). Moreover, Leaf tip necrosis (Ltn), a phenotypic marker is found to be associated with resistance to foliar blight pathogen which could facilitate selection for resistance breeding (Joshi et al., 2004a). The search for new resistance donor varieties and their employment in hybridization programme for improving host resistance should be continued so as to check spreading of disease at its lowest level and ultimately it would help in improving yield. Thus, the present investigation was undertaken for screening of wheat and barley entries against foliar blight under epiphytotic conditions in the field.

\section{Materials and Methods}

Field experiment was conducted during 201617 crop season for the evaluation of wheat and barley entries for new source of resistance against foliar blight disease. Materials under study consist of seventy five entries including released varieties, advanced breeding materials of both aestivum and durum wheat along with twenty five varieties of barley. The entries were sown as two rows of one meter length for each entry with $20 \mathrm{~cm}$ distance between rows surrounded by two rows of infector in the field. In laboratory, the multiplication of inoculum culture were made by inoculating pure culture of both the pathogen i.e. Alternaria triticina and Bipolaris sorokiniana in autoclaved sorghum seeds in separate flask then kept in incubator to attain full growth. After full growth of pathogen has attained in the substrate, spore were harvested in distilled water which act as conidial 
suspension. Inoculation was done at tillering stage by spraying the conidial suspension having spore concentration of $10^{6}$ conidia $/ \mathrm{ml}$ into the infectors by using hand sprayer during evening hours for ensuring successful infection (Chaurasia et al., 1999). After 12 days of inoculation, the characteristic brown coloured spots developed on leaves and later coalesce to each other to form a large area of leaf blight.

Disease assessment were done by recording severity of disease observed on leaves at three different crop growth stages viz. flowering, milk and hard dough stage by using the double digit scale (00-99) (Saari and Prescott, 1975) (Table 1). The left and right side digit indicate the per cent severity score of blight on flag leaf $(\mathrm{F})$ and flag-1 leaf (F-1) respectively, since these two leaves remain green at milk stage and contribute most to the grain filling process hence reduction of grain yield is directly related to disease severity in these two leaves (Kumar et al., 1998; Singh et al., 2005). The tested entries were categorized based on terminal disease severity by using described scale ranging from highly resistant to susceptible (Singh et al., 2005) (Table 3). Then, area under disease progress curve (AUDPC), an appropriate parameter to distinguish the resistance of genotypes (Van der Plank 1968; Duveiller et al., 1998), was calculated for each entry from the disease score recorded at different growth stages by the following formula (Roelfs et al., 1992).

$\mathrm{AUDPC}=\sum_{i=1}^{n}\left\{\left(\mathrm{X}_{\mathrm{i}}+\mathrm{X}_{\mathrm{i}+1}\right) \times \mathrm{t}_{\mathrm{i}}\right\} / 2$

Where $X_{i}$ and $X_{i+1}$ are disease severities on date $i$ and date $i+1$, respectively

$t_{i}$ is the number of days in between date $i$ and date $\mathrm{i}+1$

$\mathrm{n}$ is the number of observation recorded

\section{Results and Discussion}

It was observed that ten entries of wheat i.e. GW 492, GW 322, GDW 1255, Raj 4315, Raj 3765, VA 2015-30, VA 2015-41, JD 2015-18, VD 15-26, and VD 2016-1 were found no infection of foliar blight in all three stages so their values of AUDPC were zero (Table 2). The highest score of blight were recorded in two wheat varieties; Bansi and A-9-30-1 with 89 and 79 respectively, at hard dough stage. The entries were categorized based on their reaction as given in the Table 3. Among seventy five entries of wheat, it was found that fifty eight entries were having highly resistant reaction, nine entries were associated with resistant, followed by six entries with moderately resistant and there were only two entries viz., Bansi and A-9-30-1 which were characterized with susceptible reaction against foliar blight of wheat (Fig. 1). While, among twenty five entries of barley, eighteen entries were found to have disease score ranged from 11 to 57 so their reaction also ranged from HR to MR. Six entries viz., RD 2876, K 944, PL 844, BH 933, PL 751, and VW 2016-7 were associated with severity score ranging from 59 to 69 thus they were categorized as moderately susceptible reaction to foliar blight disease. Among twenty five entries of barley, it was found that three entries were having highly resistant reaction, four entries were associated with resistant followed by eleven entries were having moderately resistant and six entries were moderately susceptible (Fig. 1). While, the highest severity score of 79 were recorded in RD 2715 and categorized as susceptible reaction. Then, all hundred test entries of both wheat and barley were categorized based on their values of AUDPC (Table 4). Thirty two and eight entries of both wheat and barley were under " $1-100$ " and "101-200" group respectively followed by seventeen and eighteen entries were under "201-500" and '501-1000" group respectively. 
Fig.1 Reaction of wheat and barley entries against foliar blight

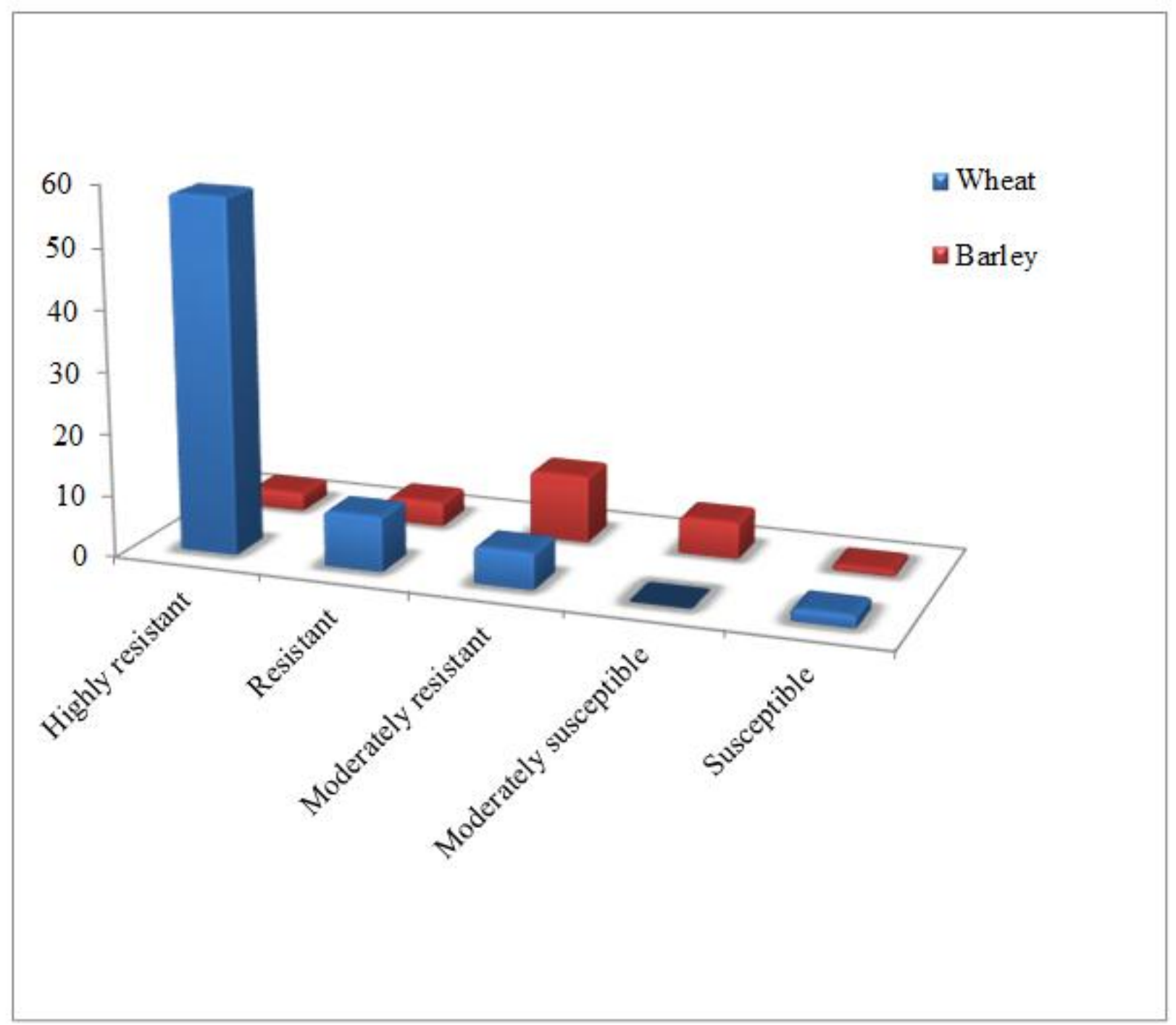

Table.1 Double digit scale for recording disease severity of foliar blight

\begin{tabular}{|l|l|}
\hline $\mathbf{0}$ & No blight \\
\hline $\mathbf{1}$ & Upto 10 per cent leaf area coverage \\
\hline $\mathbf{2}$ & $\mathbf{1 0}$ to 20 per cent leaf area coverage \\
\hline 3 & 20 to 30 per cent leaf area coverage \\
\hline 4 & 30 to 40 per cent leaf area coverage \\
\hline 5 & 40 to 50 per cent leaf area coverage \\
\hline 6 & 50 to 60 per cent leaf area coverage \\
\hline 7 & 60 to 70 per cent leaf area coverage \\
\hline 8 & 70 to 80 per cent leaf area coverage \\
\hline 9 & 80 to 90 per cent leaf area coverage \\
\hline
\end{tabular}


Table.2 Reaction of wheat and barley entries against foliar blight during 2016-17

\begin{tabular}{|c|c|c|c|c|c|c|}
\hline \multirow{2}{*}{$\begin{array}{l}\text { S. } \\
\text { N. }\end{array}$} & \multirow{2}{*}{$\begin{array}{l}\text { Entry } \\
\text { Wheat }\end{array}$} & \multicolumn{3}{|c|}{ Foliar Blight Score (dd) } & \multirow[b]{2}{*}{ AUDPC } & \multirow[b]{2}{*}{ Reaction } \\
\hline & & Flowering & Dough & Hard Dough & & \\
\hline 1 & GW 480 & 00 & 00 & 01 & 7.5 & HR \\
\hline 2 & GW 491 & 00 & 00 & 01 & 7.5 & HR \\
\hline 3 & GW 492 & 00 & 00 & 00 & 0 & HR \\
\hline 4 & GW 493 & 00 & 01 & 01 & 22.5 & HR \\
\hline 5 & GW 483 & 00 & 01 & 02 & 30 & HR \\
\hline 6 & GW 495 & 00 & 01 & 01 & 22.5 & HR \\
\hline 7 & GW 498 & 00 & 01 & 12 & 105 & HR \\
\hline 8 & GW 499 & 01 & 11 & 12 & 262.5 & HR \\
\hline 9 & GW 500 & 11 & 12 & 12 & 352.5 & HR \\
\hline 10 & GW 501 & 01 & 11 & 12 & 262.5 & HR \\
\hline 11 & GW 502 & 13 & 34 & 34 & 862.5 & $\mathbf{R}$ \\
\hline 12 & GW 504 & 23 & 37 & 38 & 1012.5 & MR \\
\hline 13 & VA 2015-09 & 01 & 02 & 12 & 127.5 & HR \\
\hline 14 & VA 2015-11 & 03 & 05 & 15 & 210 & $\mathbf{R}$ \\
\hline 15 & VA 2015-14 & 01 & 02 & 12 & 127.5 & HR \\
\hline 16 & VA $2015-18$ & 11 & 12 & 13 & 360 & HR \\
\hline 17 & VA $2015-21$ & 00 & 00 & 01 & 7.5 & HR \\
\hline 18 & VA $2015-25$ & 00 & 01 & 01 & 22.5 & HR \\
\hline 19 & VA $2015-26$ & 13 & 23 & 24 & 622.5 & $\mathbf{R}$ \\
\hline 20 & VA $2015-30$ & 00 & 00 & 00 & 0 & HR \\
\hline 21 & JD 2015-10 & 00 & 01 & 01 & 22.5 & HR \\
\hline 22 & VA $2015-38$ & 00 & 01 & 01 & 22.5 & HR \\
\hline 23 & VA $2015-41$ & 00 & 00 & 00 & 0 & HR \\
\hline 24 & VA $2015-43$ & 00 & 00 & 01 & 7.5 & HR \\
\hline 25 & JD 2015-18 & 00 & 00 & 00 & 0 & HR \\
\hline 26 & VA $2015-46$ & 12 & 14 & 16 & 420 & $\mathbf{R}$ \\
\hline 27 & VA 2015-08 & 00 & 01 & 11 & 97.5 & HR \\
\hline 28 & VA 2015-42 & 00 & 01 & 11 & 97.5 & HR \\
\hline 29 & VA $2015-44$ & 11 & 12 & 13 & 360 & HR \\
\hline 30 & VA 2015-49 & 13 & 15 & 15 & 435 & MR \\
\hline 31 & VA $2015-53$ & 00 & 01 & 01 & 22.5 & HR \\
\hline 32 & VA 2015-55 & 12 & 13 & 23 & 457.5 & $\mathbf{R}$ \\
\hline 33 & VD 15-6 & 00 & 01 & 01 & 22.5 & HR \\
\hline 34 & VD $15-7$ & 00 & 00 & 01 & 7.5 & HR \\
\hline 35 & VD 15-9 & 12 & 22 & 24 & 600 & $\mathbf{R}$ \\
\hline 36 & VD $15-13$ & 00 & 01 & 01 & 22.5 & HR \\
\hline 37 & VD 15-14 & 01 & 11 & 12 & 262.5 & HR \\
\hline 38 & VD $15-17$ & 01 & 12 & 12 & 277.5 & HR \\
\hline 39 & VD $15-18$ & 00 & 01 & 01 & 22.5 & HR \\
\hline 40 & VD 15-21 & 13 & 25 & 36 & 742.5 & MR \\
\hline 41 & VD $15-26$ & 00 & 00 & 00 & 0 & HR \\
\hline 42 & VD 2016-1 & 00 & 00 & 00 & 0 & HR \\
\hline 43 & VD 2016-2 & 00 & 00 & 01 & 7.5 & HR \\
\hline 44 & VD 2016-3 & 01 & 11 & 11 & 255 & HR \\
\hline 45 & GW 451 & 01 & 12 & 12 & 277.5 & HR \\
\hline
\end{tabular}




\begin{tabular}{|c|c|c|c|c|c|c|}
\hline 46 & GW 496 & 00 & 01 & 01 & 22.5 & HR \\
\hline 47 & GW 322 & 00 & 00 & 00 & 0 & HR \\
\hline 48 & GW 366 & 00 & 01 & 01 & 22.5 & HR \\
\hline 49 & GDW 1255 & 00 & 00 & 00 & 0 & HR \\
\hline 50 & GW 11 & 14 & 28 & 29 & 742.5 & $\mathbf{R}$ \\
\hline 51 & GW 503 & 15 & 18 & 29 & 600 & $\mathbf{R}$ \\
\hline 52 & GW 173 & 00 & 00 & 01 & 7.5 & HR \\
\hline 53 & GW 1338 & 01 & 02 & 03 & 60 & HR \\
\hline 54 & GW 1339 & 00 & 01 & 11 & 97.5 & HR \\
\hline 55 & GW 1340 & 00 & 01 & 02 & 30 & HR \\
\hline 56 & GW 1341 & 16 & 29 & 39 & 847.5 & MR \\
\hline 57 & HD 2864 & 00 & 01 & 01 & 22.5 & HR \\
\hline 58 & LOK 76 & 00 & 01 & 01 & 22.5 & HR \\
\hline 59 & LOK 1 & 00 & 01 & 11 & 97.5 & HR \\
\hline 60 & GW 2008-153 & 12 & 22 & 36 & 690 & MR \\
\hline 61 & Raj 4315 & 00 & 00 & 00 & 0 & HR \\
\hline 62 & NIAW 2302 & 11 & 12 & 13 & 360 & HR \\
\hline 63 & Raj 3765 & 00 & 00 & 00 & 0 & HR \\
\hline 64 & VL 892 & 13 & 24 & 36 & 727.5 & MR \\
\hline 65 & DL 1012 & 00 & 00 & 01 & 7.5 & HR \\
\hline 66 & PHSL-5 & 01 & 01 & 01 & 30 & HR \\
\hline 67 & GW 397 & 13 & 24 & 35 & 720 & $\mathbf{R}$ \\
\hline 68 & BWL 1664 & 00 & 01 & 11 & 97.5 & HR \\
\hline 69 & PBW 707 & 01 & 03 & 13 & 150 & HR \\
\hline 70 & DBW 14 & 00 & 01 & 01 & 22.5 & HR \\
\hline 71 & DBW 217 & 00 & 01 & 11 & 97.5 & HR \\
\hline 72 & NW 6094 & 01 & 02 & 12 & 127.5 & HR \\
\hline 73 & QLD 46 & 01 & 01 & 11 & 120 & HR \\
\hline 74 & BANSI & 36 & 79 & 89 & 2122.5 & $\mathbf{S}$ \\
\hline 75 & A-9-30-1 & 26 & 59 & 79 & 1672.5 & $\mathbf{S}$ \\
\hline \multicolumn{7}{|c|}{ Barley } \\
\hline 76 & RD 2784 & 26 & 37 & 38 & 1035 & MR \\
\hline 77 & BH 980 & 15 & 26 & 37 & 780 & MR \\
\hline 78 & BH 922 & 13 & 25 & 36 & 742.5 & MR \\
\hline 79 & KB 1369 & 24 & 37 & 48 & 1095 & MR \\
\hline 80 & RD 2875 & 13 & 25 & 38 & 757.5 & MR \\
\hline 81 & RD 2876 & 23 & 45 & 59 & 1290 & MS \\
\hline 82 & UPB 1040 & 12 & 13 & 27 & 487.5 & $\mathbf{R}$ \\
\hline 83 & EIBGN 76 & 11 & 12 & 36 & 532.5 & MS \\
\hline 84 & IBYT-HT 10 & 00 & 01 & 13 & 112.5 & HR \\
\hline 85 & BH 922 & 01 & 02 & 13 & 135 & HR \\
\hline 86 & RD 2696 & 02 & 13 & 27 & 412.5 & MR \\
\hline 87 & K 944 & 25 & 37 & 67 & 1245 & MS \\
\hline 88 & HUB 210 & 25 & 36 & 48 & 1087.5 & MR \\
\hline 89 & PL 844 & 24 & 46 & 68 & 1380 & MS \\
\hline 90 & BH 933 & 23 & 45 & 57 & 1275 & MR \\
\hline 91 & UPB 1040 & 12 & 23 & 27 & 637.5 & $\mathbf{R}$ \\
\hline 92 & UPB 1036 & 12 & 13 & 26 & 480 & $\mathbf{R}$ \\
\hline 93 & BH 970 & 11 & 24 & 26 & 637.5 & $\mathbf{R}$ \\
\hline
\end{tabular}




\begin{tabular}{|l|l|l|l|l|c|c|}
\hline $\mathbf{9 4}$ & RD 2035 & 03 & 25 & 36 & 667.5 & MR \\
\hline $\mathbf{9 5}$ & RD 2052 & 23 & 46 & 49 & 1230 & MR \\
\hline $\mathbf{9 6}$ & RD 2552 & 15 & 47 & 48 & 1177.5 & MR \\
\hline $\mathbf{9 7}$ & RD 2715 & 26 & 59 & 79 & 1672.5 & S \\
\hline $\mathbf{9 8}$ & PL 751 & 36 & 58 & 69 & 1657.5 & MS \\
\hline $\mathbf{9 9}$ & Raj 4132 & 00 & 01 & 11 & 97.5 & HR \\
\hline $\mathbf{1 0 0}$ & VW 2016-7 & $\mathbf{2 7}$ & $\mathbf{5 9}$ & $\mathbf{6 9}$ & $\mathbf{1 6 0 5}$ & MS \\
\hline
\end{tabular}

Table.3 Categorization of disease reaction based on severity score of foliar blight

\section{Double digit scale}

\begin{tabular}{|c|}
\hline $00-13$ \\
\hline $14-35$ \\
\hline $36-57$ \\
\hline $58-78$ \\
\hline$>78$ \\
\hline
\end{tabular}

\section{Disease reaction}

Highly resistant (HR)

Resistant (R)

Moderately resistant (MR)

Moderately susceptible (MS)

Susceptible (S)

Table.4 Categorization of wheat and barley entries based on AUDPC

\begin{tabular}{|c|c|}
\hline AUDPC & Entries \\
\hline 0 & $\begin{array}{l}\text { GW 322, GW 492, GDW 1255, Raj 4315, Raj 3765, VA 2015-30, VA } 2015- \\
\text { 41, JD 2015-18, VD 15-26, VD 2016-1 }\end{array}$ \\
\hline $1-100$ & $\begin{array}{l}\text { GW 173, GW 480, GW 483, GW 491, GW 493, GW 495, GW 496, GW } \\
1338 \text {, GW 1339, GW 1340, LOK 1, LOK 76, DL 1012, Raj 412, PHSL-5, } \\
\text { BWL-1664, DBW14, DBW 217, HD 2864, VA 15-06, VA 15-07, VA 15-08, } \\
\text { VA } 15-13 \text {, VA 15-18, VA 15-21, VA 15-25, VA } 15-38 \text {, VA } 15-42 \text {, VA } 15- \\
\text { 43, VA } 15-53 \text {, VA } 16-02 \text {, JD } 15-10\end{array}$ \\
\hline $101-200$ & $\begin{array}{l}\text { GW 498, VA 15-09, VA 15-14, BH 922, IBYT-HT-10, PBW 707, NW 6094, } \\
\text { QLD } 46\end{array}$ \\
\hline 201-500 & $\begin{array}{l}\text { GW } 451 \text {, GW } 366 \text {, GW } 499 \text {, GW 500, GW 501, UPB } 1040 \text {, UPB } 1036 \text {, RD } \\
2696 \text {, NIAW 2302, VA } 15-11 \text {, VA } 15-14 \text {, VA } 15-17 \text {, VA } 15-18 \text {, VA } 15-44, \\
\text { VA } 15-46 \text {, VA } 15-49 \text {, VA } 15-55 \text {, VA } 16-03\end{array}$ \\
\hline $501-1000$ & $\begin{array}{l}\text { GW 11, GW 397, GW 502, GW 503, GW 1341, GW 2008-153, VA 15-9, } \\
\text { VA 15-21, VW 15-26, BH 980, BH 922, RD 2875, EIBHN-76, UPB 1040, } \\
\text { BH 970, RD 2035, VL } 892\end{array}$ \\
\hline $1001-1500$ & $\begin{array}{l}\text { GW 504, RD 2052, RD 2552, RD 2876, RD 2784, KB 1369, K944, HUB } \\
\text { 210, PL 844, BH } 933\end{array}$ \\
\hline $\begin{array}{l}1501-2000 \\
\text { and above }\end{array}$ & RD 2715, PL 751, VW 2016-7, Bansi, A-9-30-1 \\
\hline
\end{tabular}


While, five entries were under higher values of AUDPC ranging from " $1500-2000$ and above" group which were characterized with moderately susceptible to susceptible reaction in field condition (Table 4).

The above findings were also supported by similar findings which reported that out of sixty two wheat genotypes evaluated against spot blotch under natural epiphytotic conditions, eight genotypes viz., HD-2967, HD-3043, HP1102, HS-277, JAUW-598, PBW-660, PBW692 and VL-907, were observed as resistant having disease severity of 34.26 to 35.0 per cent and AUDPC values of 330.90-402.80 while twenty four genotypes were observed as moderately resistant having disease severity of 39.45 to 57.0 per cent and AUDPC values of 429.60-742.10 (Singh et al., 2018). Similarly, screening of two hundred wheat germplasm accessions against spot blotch has revealed that four and seventy eight accessions were found to be highly resistant and resistant respectively, on the basis of their AUDPC values over two years which could be act as valuable source of resistance for the development of spot blotch resistant varieties of wheat (Latwal et al., 2016).

From the result of above findings it can be concluded that entries which exhibits highly to moderately resistant reaction with lower values of AUDPC suggested that disease development were quite slow in these entries under high disease pressure of artificial epiphytotic condition in the field condition. Thus, these diverse sources of resistant entries can be used for enhancing resistance breeding programme for development of foliar blight resistant variety of wheat and barley.

\section{References}

Acharya, K., Dutta, A.K. and Pradhan, P. 2011. Bipolaris sorokiniana (Sacc.) Shoem: The most destructive wheat fungal pathogen in the warmer areas. Australian Journal of Crop Science, 5: 1064-1071.

Ahmed, M.U. and Ahmed, H.U. 1994. Disease management, recommendation and future plan of oilseeds crop in Bangladesh. In Proc. Workshop on transfer of technology of CDP crops under Research Extension Linkage programme. pp. 46-56.

Anahosur, K. 1978. Alternaria triticina. Descriptions of fungi and bacteria. IMI. No.583. Wallingford, UK: Cab International.

Beshir, M. 1994. Susceptibility of some wheat cultivars to Alternaria triticina and the biochemical changes associated with infection. Annals of Agricultural Science, 32: 899-909.

Chand, R., Pandey, S.P., Singh, H.V., Kumar, S. and Joshi, A.K. 2003. Variability and its probable cause in natural populations of spot blotch pathogen Bipolaris sorokiniana of wheat ( $T$. aestivum L.) in India. Journal of Plant Diseases and Protection, 110(1): 27-35.

Chaurasia, S., Chand, R. and Joshi, A.K. 2000. Relative dominance of Alterneria triticina pras. et prab. Bipolaris sorokiniana (Sacc.) Shoemaker in different growth stages of wheat (T. aestivum L.). Journal of Plant Diseases and Protection, 107: 176-181.

Chaurasia, S., Joshi, A.K., Dhari, R. and Chand, R. 1999. Resistance to foliar blight of wheat: a search. Genetic Resources and Crop Evolution, 46(5): 469-475.

Dubin, H.J. and Van Ginkel, M. 1991. The status of wheat diseases and disease research in warmer areas in Saunders da Hettel $G$ eds. Wheat for Non-traditional Warm Areas, Foz de Iguazu, Brazil/Mexico, UNDP/CIMMYT.125145.

Duveiller, E. 2004. Controlling foliar blights of wheat in the rice-wheat systems of Asia. Plant Disease, 88: 552-556.

Duveiller, E. and Sharma, R.C. 2009. Genetic improvement and crop management strategies to minimize yield losses in warm non-traditional wheat growing areas due to Spot blotch pathogen Cochliobolus sativus. Journal of Phytopathology, 157: 521-534. 
Duveiller, E., Garcia, I., Franco, J., Toledo, J., Crossa, J. and Lopez, F. 1998. Evaluating spot blotch resistance of wheat: Improving disease assessment under controlled condition and in the field. In: Helminthosporium blights of wheat: Spot blotch and Tan spot (Duveiller, E., Dubin, H.J., Reeves, J., McNab, A. eds.) Mexico. D.F., Mexico: CIMMYT. pp. 63-66.

Duveiller, E., Kendel, Y. R., Sharma, R. C. and Shrestha, S. M. 2005. Epidemiology of foliar blights (spot blotch and tan spot) of wheat in the plains bordering Himalayas. Phytopathology, 95: 248-256

Guo, J.R., Schnieder, F., Abd- Elsalam, K.A. and Verreet, J.A. 2005. Rapid and efficient extraction of genomic DNA from different phytopathogenic fungi using DNAzol reagent. Biotechnological Letters, 27: 3-6.

Joshi, A.K. and Chand, R. 2002. Variation and inheritance of leaf angle and its association with spot blotch (Bipolaris sorokiniana) severity in wheat (Triticum aestivum). Euphytica, 124: 283-291.

Joshi, A.K., Chand, R, Kumar, S. and Singh, R.P. 2004a. Leaf tip necrosis: A phenotypic marker associated with resistance to spot blotch disease in wheat. Crop Science, 44: 792-796.

Joshi, A.K., Chand, R. and Arun, B. 2002. Relationship of plant height and days to maturity with resistance to spot blotch in wheat (Triticum aestivum). Euphytica, 124: 283-289.

Joshi, A.K., Kumar, S., Chand, R., Ortiz, F.G.2004b. Inheritance of resistance to spot blotch caused by Bipolaris sorokiniana in spring wheat. Plant Breeding, 123: 213-219.

Joshi, A.K., Ortiz-Ferrara, G., Crossa, J., Singh, G., Alvarado, G., Bhatta, M.R., Duveiller, E., Sharma, R.C., Pandit, D.B., Siddique, A.B., Das, S.Y., Sharma, R.N. and Chand, R. 2007. Associations of environments in South Asia based on spot blotch disease of wheat caused by Cochliobolus sativus. Crop Science, 47: 1071-1081.
Khudhair, M.W., Aboud, H.M., Dheyab, N.S., Ali, K.S. and. Khalaf, H.S. 2014. The first record of Alternaria triticina the causative agent of Alternaria leaf blight in wheat and barley in Iraq. International Journal of Phytopathology, 3(3): 133138.

Kumar, A., Solanki, I.S. and Kumari, S. 2014. Management of foliar blight (spot blotch) of wheat the most threatening disease of North Eastern Plain Zone (NEPZ) through Chemicals. Journal of Agroecology and Natural Resource Management, 1(1): 4-6.

Kumar, J., Singh, G. and Nagarajan, S. 1998. Applied scale for leaf blight recording. Indian Wheat Newsletter, 12(3):

Latwal, C., Deepshikha, Kumari, B., Singh, P.K. and Jaiswal. J.P. 2016. Characterization of bread wheat germplasm for spot blotch resistance and its association with yield and yield related traits. Journal of Wheat Research, 8(2): 31-37.

Logrieco, A. and Bottalico, A., Solfrizzo, M. and Mule, G. 1990. Incidence of Alternaria species in grains from Mediterranean countries and their ability to produce mycotoxins. Mycologia, 501505.

Maraite, H., Di Zinno, T., Longree, H., Daumerie, V. and Duveiller, E. 1998. Fungi association with foliar blight of wheat in warm areas. In: Duveiller, E., Dubin, H.J., Reeves, J., McNab, A., eds. Helminthosporium blight of wheat: Spot blotch and $\tan$ spot. Mexico, DF: CIMMYT. 293-300.

Mishra, A., Patel, N.M., Patel, D.B., Patel, J.R. and Jadon, B.S. 1989. Economical spray schedule for the management of leaf blight/blotch of wheat. Pestology, 13(8): 22-25.

Mishra, V.K., Biswas, S.K. and Rajik, M. 2011. Biochemical mechanism of resistance to Alternaria blight by different varieties of wheat. International Journal of Plant Pathology, 2: 72-80. 
Perello, A. and Sisterna, M. 2006. Leaf blight of wheat caused by Alternaria triticina in Argentina. Plant Pathology, 55: 303.

Prabhu, A. S. and Prasada, R. 1970. Investigations on the leaf blight disease of wheat caused by Alternaria triticina. Indian Phytopathology, 23: 19-27.

Prabhu, A.S. and Prasada, R. 1966. Pathological and epidemiological studies on leaf blight of wheat caused by Alternaria triticina. Indian Phytopathology, 19: 95-111.

Raut, J., Guldhe, S. and Wangikar, P. 1983. Seed-borne infection of Alternaria triticina in wheat and its control. Indian Phytopathology, 36: 274-277.

Roelfs, A.P., Singh, R.P. and Saari, E.E. 1992. Rust diseases of wheat: Concepts and methods of disease management. CIMMYT, Mexico.

Saari, E.E. and Prescott, J.M. 1975. A scale for appraising the foliar intensity of wheat disease. Plant Disease Reporter, 59: 377380.

Satvinder, K., Nanda, G.S., Navneet, G., Kaur, S.M. and Ghuman, N. 2002. Status of seed health and facultative foliar pathogens of wheat in Punjab from 19921999. Journal of Research, 39(1): 28-34.

Sharma, A.K., Singh, D.P., Kumar, J., Singh, A.K. and Nagarajan, S. 1998. Progress Report 1997-98 Vol. V Plant Protection (Pathology and Nematology). Karnal, India: Directorate of Wheat Research.

Sharma, R.C., Duveiller, E. and Ortiz-Ferrara, G. 2007. Progress and challenge towards reducing wheat spot blotch threat in the Eastern Gangetic plains of South Asia: Is climate change already taking its toll? Field Crops Research, 103: 109-118.
Singh, D.P., Kumar, P. and Singh, S.K. 2005. Resistance in wheat genotypes against leaf blight caused by Bipolaris sorokiniana at seedling along with adult plant stage. Indian Phytopathology, 58: 344.

Singh, D.P., Sharma, A.K., Tewari, A.N., Singh, K.P., Singh, A.K., Singh, R.N., Singh, S.P., Kalappanawar, I.K., Dodan, D.S. and Singh, V.K. 2004. Assessment of losses due to leaf blight in popular varieties of wheat under different sowing conditions and agro climatic zones in India. Indian Journal of Agricultural Sciences, 74(2): 110-113.

Singh, D.V., Srivastava, K.D., Agarwal, R. and Bahadur, P. 1993. Wheat disease problems: The changing scenario. In: Pest and Pest Management in India-The changing scenario. (Eds. H.C. Sharma and M. Veerabhadra Rao) Plant Protection Association of India, Hyderabad, pp.116-120.

Singh, S.K., Singh, M., Razdan, V.K., Singh, V.B., Singh, A.K., Gupta, S., Singh, R., Gupta, A., Shankar, U, Singh, A.K., Pandey, M.K. and Sharma, R. 2018. Prevalence of spot blotch (Bipolaris sorokiniana) of wheat and its management through host resistance. International Journal of Current Microbiology and Applied Sciences, 7(2): 686-694.

Van der Plank, J.E. 1968. Disease resistance in plants. Academic Press, New York and London. 206p.

Waller, J. 1981. The recent spread of some tropical plant diseases. International Journal of Pest Management, 27: 360362.

\section{How to cite this article:}

Elangbam Premabati Devi and Patel, S.I. 2018. Characterization of Wheat and Barley Entries for Foliar Blight Resistance. Int.J.Curr.Microbiol.App.Sci. 7(08): 4108-4117. doi: https://doi.org/10.20546/ijcmas.2018.708.427 